\title{
Some Current Developments in Brazilian Sociology of Crime: Towards a Criminology?
}

\author{
Renan Springer de Freitas* and Ludmila Ribeiro*
}

\author{
Department of Sociology, Federal University of Minas Gerais, Belo Horizonte, MG, Brazil
}

\begin{abstract}
This paper discusses the directions taken by sociology of crime in Brazil ever since its appearance, in the dawn of the 1970s, as well as the factors that prevented the development of a true criminology in the country, similar to that already found in North America. It is herein argued that while, on the one hand, Brazilian sociology was indeed able to develop an agenda of research on the processes that account for the criminalization of poorer segments of the population, on the other hand, for not having paid due attention to an entire consolidated body of knowledge available in order countries, it failed to explain rises and declines in criminality rates, and likewise failed to prescribe effective related public policies.
\end{abstract}

Keywords: Sociology of crime, criminology, Brazilian sociology.

The title of this paper must be taken literally. We discuss some current developments in Brazilian sociology of crime, notably those which are related with the fact that no criminology as a distinct academic discipline has yet properly developed in Brazil. We must promptly say that undertaking this task does not involve presenting a thorough literature review, ${ }^{1}$ nor a survey of the main sociologists working in this field, ${ }^{2}$ not even a summary of outputs from research centers focused on this matter.

Appearing in the early $1970 \mathrm{~s}^{3}$, the first studies on criminality in Brazil were notable for ignoring all the specialized literature amassed by then, and for placing a bet, instead, either on the formulation of a "native theory of violence and of the violent", supposedly capable of explaining the "roots of violence" in Brazil, or on the heuristic potential of other more widely

*Address correspondence to these authors at the Federal University of Minas Gerais, FAFICH, Department of Sociology, Av. Antonio Carlos 6627, Campus UFMG, CEP 31270-901, Belo Horizonte, MG, Brasil;

E-mail: springer@netuno.lcc.ufmg.br, ludmila.ribeiro@gmail.com

\footnotetext{
${ }^{1}$ Literature reviews in the field of Sociology of Crime were produced four times until today and are summarized in the following publications: Adorno (1993), Zaluar (1999), Kant de Lima et al. (2001), Adorno e Barreira (2010).

${ }^{2}$ Some research centers that were developed in order to study crime, public security and criminal justice are the Núcleo de Estudos da Violência (NEV/USP), which is probably the oldest one in Brazil and differs from the others since it focus on questions more related to political science issues as the obstacles that crime victimization and violence implies for a fully democratization of the country; Núcleo de Estudos da Cidadania Conflito e Violência (NECVU/UFRJ); Laboratório de Estudos da Violência (LEV/UFC), Núcleo de Estudos e Pesquisas em Criminalidade, Violência e Políticas Públicas de Segurança (NEPS/UFPE); Centro de Estudos de Segurança e Cidadania (CESeC/UCAM) and others that focus on crime trends and the development of public security and criminal justice policies and, because of this, some of them may be better classified as a think thank.

${ }^{3}$ For a rich description of the early days of the discussion about violence and criminality in Brazil, see Zaluar (2004) in special page 229 and following.
}

encompassing theories, produced at the margin of criminality studies. That bet on a "native theory" led to the thesis according to which, in Brazil, violence had its roots in the rural areas, where it appears as a mechanism for solving interpersonal conflict, as an expression of the incapacity - which was expected to be later corrected by the transition to modernity - to bring into the public arena the solution to conflicts until then resolved within the private realm. ${ }^{4}$ The bet on the heuristic potential of sociological theories, in turn, led to the thesis that, in urban areas, crime is a "survival

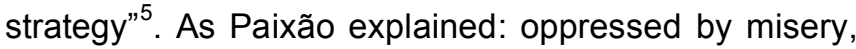
experiencing sharp inequalities and held back in their aspirations by class barriers, the slum dwellers, the unemployed, unskilled workers and other contingents of urban marginality would thus be attracted to criminal activities as they came to realize that gains arising from crime were higher than the benefits obtainable from legal activities. ${ }^{6}$ Paradoxically, a thesis of such nature can be seen as a legacy both from Marxist thought and from the famed writings by Merton on "deviant behavior".

As late as in the 1970s, criminality studies produced in Brazil still ignored the specialized foreign literature (see Annex 1). Whatever the reasons for this ignorance had been," in a paper entitled "Sobre sociólogos,

\footnotetext{
${ }^{4}$ DaMatta (1982)

${ }^{5}$ Oliven (1980)

"Paixão (1983, p. 41). It should be said that the "survival strategy" thesis was not proposed by Paixão himself. He mentions it only to criticize it next. But his description seemed so impeccable to us that we decided to reproduce it here. ${ }^{7}$ To Michel Misse (2008), the reasons for this lack of knowledge (at least in the early 1970s) could be found in the myth of national identity, as Brazil was still conceived at the time as "a country populated by cordial people, a country without violence, a peaceful country", an idea which ultimately rendered unfeasible the setting of a research agenda for the area, "while in the United States and Europe the research in criminality reached their academic apogee" (p. 372).
}

(C) 2014 Lifescience Global 
pobreza e crime" (On sociologists, poverty and crime), published in 1980, Edmundo Campos Coelho was the first to point out that a change in direction was imperative. The paper arrived at a rather gloomy diagnosis on the situation of criminality studies in Brazil:

All things considered, what stands out from the public debate on the growing criminality rates in Brazilian metropolises is the mediocre contribution by us social scientists. (...) Little of what we have been saying is of any use. And this even though [North-American and European] sociology has - over the past three or four decades - produced a well-nurtured, fecund literature in the area of criminology, together with a vast array of empirical information. Admittedly, we [Brazilian] social scientists cannot be expected anytime soon to put aside - even if just provisionally - our tradition of abstract, totalizing theorizations, and instead assimilate and select whatever may be relevant in that topic literature for shedding light on native criminality. ${ }^{8}$

In that being the case, it remains for us to know: 1) what was in that "well-nurtured, fecund literature" which would make it then (or still now) indispensable for criminality studies in Brazil? 2) to what extent have these studies incorporated contributions from that literature, over the thirty years or so that have elapsed since the aforementioned paper was written, and to what gain(s)? 3) would such contribution itself have "advanced" somehow over the past thirty years? 4) if so, to what extent has the area of studies on criminality in Brazil benefitted or not from such advance?

In Coelho's view, the contributions that Brazilian sociologists should have learnt from - but which they had not, even as the 1980s started - had to do with the way official statistics on criminality rates were put together. "I suppose [our] social scientists are aware of the existing studies on the nature of such statistics and on the serious biases they introduce in the analysis", he stated with ill-disguised irony in the aforementioned 1980 paper. Needless to say, any effort to explain criminality rates requires some sort of statistical survey informing what after all is the criminality rate intended

\footnotetext{
${ }^{8}$ Free translation from Coelho (1980[2005], p. 289-290).
}

to be explained. Thus, in order to associate crime to poverty, as local studies did until then, it is necessary to have some statistical survey indicate the number of crimes committed by poor and by rich people in a defined time and in a defined place. As the only statistical surveys available back in the early 1980s were those produced by official agencies, the aforementioned studies accepted them (explicit or implicitly) uncritically. During the 1960s and 1970s, however, a vast literature was produced in the Unites States to demonstrate that said official statistics suffer from irremediable biases. This means that taking official statistics as a basis to postulate whatever it is one wish to postulate is a mistake that compromises any interpretative effort from the very start.

Statistics produced by official agencies devoted to control and repress crime are fundamentally based on filed complaints, solved cases and arrests made. In all such cases, offenses committed by persons belonging to higher social classes are not accounted for in the same proportion as those involving people from lower classes. The only way to avoid this problem would be to select cases for study independently from the statistics produced by the official system, which can only be done by opinion polls or by a nationwide survey on victimization.

In the United States this was already being done as of the 1950s! Works such as "Socioeconomic Status and Delinquent Behavior", of $1958,{ }^{9}$ "From delinquent behavior to official delinquency", of $1972,{ }^{10}$ and "Group violations, socio-economic status and official delinquency", of $1973,{ }^{11}$ constitute a good sample showing how far criminality studies had already advanced in that direction. They reveal the huge difference it makes when the research produces and relies on its own database instead of resorting to data produced by official agencies:

Especially in the area of delinquency, studies rely more and more on representative national samples of youth from all socioeconomic strata, or on interviews with samples of delinquents based on investigation schemes especially

\footnotetext{
${ }^{9} \mathrm{~F}$. Ivan Nye, James F. Short, Jr. and Virgil J. Olson, "Socioeconomic status and delinquent behavior”, American Sociological Review, 63(4):381-389, Jan. 1958.

${ }^{10} \mathrm{R}$ Jay Williams, Samuel C Foster, "From delinquent behavior to official delinquency", Social Problems, 20(2):209-229, 1972.

${ }^{11}$ Maynard L. Erickson, "Group violations, socio-economic status and official delinquency”, Social Forces, Vol. 52, No. 1 (Sep., 1973), pp. 41-52.
} 
designed for that purpose: comparisons between information obtained from such interviews against police records, and between the results of such studies and those using more conventional national samplings, have led to surprising discoveries. As it should be expected, they reveal that the extent of covert delinquency - violations committed and not detected by the police - is considerable; and even more importantly, that youth of higher socioeconomic status are the ones who break the law more often and more seriously. At the very least, the results from such investigations show that there are no significant differences between social classes when it comes to incidence of delinquency. What does happen - and is reflected in official statistics - is that people of lower classes cannot count on the institutional immunities that protect those of middle and high classes and, for this reason, are more likely to be detected by the police, arrested, prosecuted and convicted. ${ }^{12}$

For this reason, argues Coelho, subscribing to the thesis of a positive correlation between poverty and criminality implies endorsing "not only the distortions of official data, but further - and much more seriously the perverted police practices which produce them. Even worse still, [this way] one subscribes to the legal (official) definition of 'criminal behavior', leaving at the margin of critical reflection the mechanisms of power that inform and shape the production of criminal laws." 13

It was thus proposed, for the first time ever in Brazil, a specific investigative agenda for the area of criminality: studying the mechanisms by means of which "the production of criminal laws is informed and formed." From Coelho's perspective, basing one's research on official statistics (or ignoring their biased nature) was not merely a technical problem. Such mistake, this "vice of origin", as he called it himself, insofar as it led to the conclusion that criminality is associated to poverty, would involve another deeper error, namely, that of assuming that there is something peculiar relative to the poorer segments of the

\footnotetext{
${ }^{12}$ Free translation from Coelho (1978[2005], p. 280), emphases added

${ }^{13}$ Free translation from Coelho (1980[2005], p. 289).
}

population (for instance, their not having been socialized according to "modern" standards of conduct) which would make them intrinsically more inclined to entering "the underworld of crime".

Now, reasoned Coelho, this assumption is typical of the official control agencies. In view of which, it is up to sociological thought to turn it into a subject of research, instead of uncritically subscribing to it - which was precisely what had been happening, as we saw above. Far from investigating the range of routine practices by means of which the police and the judicial system ended up by criminalizing poverty, Brazilian sociologists - as they insisted in seeking the causes of criminal conduct (without subjecting official statistics to critical scrutiny) - were simply and unreflectively adopting a "theory of crime" that was in fact the very "theory" that instructed the actions of official control agencies. This prevented the setting up of an appropriate research agenda for the area of studies on criminality:

the issues that really matter and which are at the core of the problem only rarely occur to experts. Why is one same behavior a legal offense when enacted by a certain class of people, but not so when it is enacted by individuals of other classes? What are the mechanisms and processes through which certain behaviors are legally considered as criminal, while other essentially identical behaviors are not? ${ }^{14}$

Now that more than thirty years have elapsed since those words were written, what has been made of the issues thus raised? First of all, it is necessary to point out that, if in Brazil such issues would only "rarely occur to experts", this was not due to any lack of available exemplary literature. As early as in 1968, Aaron V. Cicourel had published The Social Organization of Juvenile Justice, whose theme was precisely "the mechanisms and processes through which certain behaviors are legally considered as criminal, while other essentially identical behaviors are not".

Fourteen years later, i.e., in 1982, that book would find echo in Brazil for the first time with the publication of Antônio Luiz Paixão's "A Organização Policial numa Área Metropolitana" (Police Organization in a

\footnotetext{
${ }^{14}$ Coelho (1978[2005], p. 280), italic adds.
} 
Metropolitan Area). By now numbering over 1000 citations, ${ }^{15}$ the paper emulates, so to say, the classical work of Cicourel, to argue that the police - the entry gate into criminal justice -, given the impossibility of being everywhere all the time, ends up by selecting some spaces and individuals as the preferred focuses of their action:

the policeman's "logic in use" normally implies an inversion of legal formalisms for prosecuting criminals. More than legal categories, organizationally formulated ideologies and stereotypes are what guides the action of "line" members [of the police force] in their routine activities, and said ideologies and typifications render the police action more 'economical' insofar as it is concentrated on the surveillance and control of the "dangerous classes". ${ }^{16}$

As the policeman officers start off from their own assumptions - which themselves, we must add, are a result of ideologies and stereotypes shaped in the exercise of police activity - with regard to which strata of the population are particularly inclined towards conduct deviations, they end up performing, in their own view, the role of "garbage men" of society, removing from nobler parts of town that undesired waste - seen as such specially from an aesthetic point of view. ${ }^{17}$ But, if this is so, how do the poorer segments of the population react to such stereotyped perception (entertained by the police) which ends up by criminalizing them?

Among works dealing in this theme, a highlight is $A$ Máquina e a Revolta (The Machine and the Revolt), by Alba Zaluar, published in 1985. As she studied a wellknown housing complex in Rio de Janeiro, ${ }^{18}$ which, at that time, was the core around which a huge slum was forming, Zaluar describes the social misery of those who had been removed into that area, which then starts being marked by acts of banditry, violence, filth, immorality, promiscuity, typical of "uncultured" and "dangerous" individuals. Described as the urban poor, averse to civilization, those dwellers would revolt against the "machine" operationalized by police action, and which sought to classify them homogeneously as

\footnotetext{
${ }^{15}$ Google Scholar retrieves 1,090 results when the expression is typed between quotation marks (access on 26 October 2012)

${ }^{16}$ Free translation from Paixão (1982, p. 64).

${ }^{17}$ Paixão (1982, p. 80).

${ }^{18}$ This refers to the Cidade de Deus housing complex, depicted in a feature film of same name, directed by Fernando Meireles and launched in Brazil in 2002.
}

"criminals". In their reaction, they strove to be recognized as workers, an identity built at least partially "as opposed to bandits and vagabonds who did not work for a living". The big problem with this was that the revolt had as its main interlocutor the state machine itself, which renders rather gloomy the final diagnosis of Zaluar's paper with regard to the likelihood of lessfavored segments of society managing to rid themselves from the usual labels assigned to them by the police.

In a very conservative estimate, some 800 papers were published dealing in criminality studies over the twenty years following the aforementioned works by Coelho and Paixão. ${ }^{19}$ During the subsequent 10 years, i.e., from 2000 to 2010, another 1374 papers were produced. $^{20}$ This makes it at least 2200 papers produced over the past 30 years. There is no way we can determine how many of these followed the investigative path envisaged by Coelho's pioneer work. But the fact is that, in perfect harmony with that author's proposal, a lot of research did focus on the modus operandi of the Brazilian criminal justice system, seeking to show the extent to which this system acts selectively. For illustration purposes, it suffices to mention a recent paper by Michel Misse, in which the author purports to distinguish the stages by which a "criminal" is constructed from the judicial viewpoint. $^{21}$

To Misse, that "construction" happens along four stages: "criminalization", so named for referring merely to the definition of acts potentially definable as "criminal", regardless of the existence of the figure of a criminal; then follows "crimination", a stage at which it is defined whether this or that act committed by this or that individual, in a particular circumstance, is or not "criminal"; then comes "incrimination", which consists of the "appointment of authorship, for subsequent search and punishment of its causal subject" ${ }^{22}$ and, finally, the "criminal subjection", a stage that takes place when

\footnotetext{
${ }^{19}$ According to a count by Kant de Lima et al. made in the year 2000 , as many as 1166 papers were written by scholars active in Brazil during the 1970-2000 period. Had these papers been produced in proportional amounts over decades (which is highly improbable), then the 1980-2000 period would account for two-thirds of that total, i.e., about 800 papers. As the pace of production actually tends to speed up with the passing time, it is very likely that, from the aforementioned 1166 papers, many more than 800 correspond to the $1980-2000$ period

${ }^{20}$ This is based on a survey by Barreira and Adorno (2010). It should be stressed that these figures look rather impressive if we keep in mind that in the previous thirty years, i.e., over the 1970-2000 period, the total number of papers was 1166 .

${ }^{21}$ See Misse (2008). Misse makes no mention of Edmundo Campos Coelho, but perhaps his work counts among those that more clearly reverberates the latter's call for changes in direction.

${ }^{22}$ Misse (2008, p. 380)
} 
incrimination precedes crimination (or even criminalization) in a regular fashion. At this stage, "the focus shifts from the event to the subject and from the crime to the virtual criminal". In other words, this is the stage at which one searches for

the subject of a crime which has not happened yet. If the crime has already taken place and if the individual in question has been incriminated before, for some other crime, he/she then becomes a 'crime-inclined subject', a potential suspect. If his/her social characteristics can be generalized to other subjects like him/her, then a stigmatized 'social type' is created. But criminal subjection is more than a stigma, as it does not relate only to labels, to the incorporation of roles and careers by the criminal (as in Lemert's "secondary criminalization"). It realizes the full merging of the event with its author, even when the event is only potential and has not actually taken place. It is an entire process of subjectification that runs its course in this internalization of crime into the subject who bears it and who shall carry it on him/herself like a 'ghost' that has taken up his body and soul. ${ }^{23}$

More than thirty years ago, Coelho would assert, as we have seen above, that "what matters" is to describe "the mechanisms and processes through which certain behaviors come to be legally considered as criminal, while other essentially identical behaviors are not". In a paper published in 1982, Paixão described one of such mechanisms: the police starts up the inquiry "last things first", beginning by arresting suspects and only then proceeding to the investigation. ${ }^{24}$ As Misse postulates that the police organization regularly operates by "incriminating" prior to "criminating", i.e., by searching for "the subject of a crime that has not happened yet", he ends up by demonstrating that the mechanism described by Paixão is part of this more comprehensive process which he called "criminal subjection".

But, after all, who would be this "subject of a crime that has not happened yet"? There is an entire collection of papers dealing in this matter. One of them shows that young dark-skinned male defendants, of low level of education, whose investigative inquiry has

\footnotetext{
${ }^{23}$ Free translation from Misse (2008, p. 380)

${ }^{24}$ Paixão (1982, p. 75)
}

been initiated at the police from a detention in flagrante delicto, are more likely to end up being convicted than older female white defendants of higher levels of education. ${ }^{25}$ Results of such nature reinforce the notion that the Brazilian criminal justice system has its operation set in motion by targeting those who fit the typical stereotypes of "criminal subjectification" and who therefore are more likely to "survive" all stages along the flow ${ }^{26}$ and consequently get convicted in the end.

One notes, thus, that the selective investment in the "well-nurtured, fecund literature in the area of criminology", amassed and consolidated over "three or four decades", to which Coelho referred in his 1980 paper, as aforementioned, yielded decades of useful discussion on the way the Brazilian criminal justice system works and how it criminalizes certain segments of the population. But this is not all there is to it. As we have seen, the main lesson that Coelho derived from said literature, at least initially, was that it would be useless - if not deleterious - to invest in causal explanations of criminal behavior, as this would imply that there is something intrinsically wrong with regard to whoever incurs in it. But, precisely for having been consolidated over three decades or more, that literature pointed to a variety of possible directions, one of them being exactly that of the setting up of criminology as an autonomous discipline whose objective was no other than causally explaining criminal behavior.

Following a trend initiated already in the 1970s, the decades of the 1980s and 1990s saw a veritable boom of criminology departments in the United States and Europe, as well as in some Latin American countries such as Mexico, Chile and Argentina. As an autonomous academic discipline, criminology appeared in the United States in the late 1960s, when the aforementioned buildup of sociological studies on crime, criminals and workings of the criminal justice (some of whose paradigmatic publications are listed in Annex 1) led it to gradually detach from its sociological matrix and towards an identity of its own.

Now transformed in "criminological studies", they progressively incorporated ever more sophisticated

\footnotetext{
${ }^{25}$ In this sense, see Adorno (1995) analyses of selecting and screening standards applied by the Brazilian criminal justice to crimes such murder.

${ }^{26}$ The flow of the criminal justice system can be described by reference to its "critical" stages, namely: report recorded by the military police, criminal investigation by the civil police, filing of information (or pressing of charges) by the Public Prosecutor's Office, procedure and judgement by the Judiciary. Survival, in this context, means not escaping any of these phases and, therefore, being judged and possibly convicted at the final stage. For further reference on this system's working standards, see Vargas (2014).
} 
statistical techniques, which, used together with traditional methodologies (interviews, participating observation), led to the setting up of an agenda of empirical investigation not even conceivable in the strictly sociological terrain. Thus, in 1968, Gary Becker designs an econometric model divided into five analytical dimensions, with the purpose of testing relations between number of criminal offenses and 1 ) social cost of crime; 2) cost of arrest and punishment; 3 ) probability of prisons and convictions and expenses with the upkeep of police and courts; 4) cost of maintaining the prison system and other modes of punishment; and 5) private sector expenditures with security.

In 1985, while researching the files of Sheldon and Elanor Glueck ${ }^{27}$, John Laub comes across a series of questionnaires that gathered information about 500 adolescents classified as criminals and 500 others classified as non-criminals, from ages 10 to $17^{28}$. The information had been systematically collected between 1949 and 1963, which meant that the database brought together detailed information about what had happened in the life of those individuals during the period from 25 to 32 years of age. In association with Robert Sampson, Laub analyzes the first part of that database, getting in renewed contact with the 500 adolescents classified as criminals until they turned 70 -year-olds, while further conducting in-depth interviews with 52 of them. From all this material, those authors published two classics of the specialized literature. In the first of these, ${ }^{29}$ they put forth a theory of life cycles combined with an idea on how informal controls influence the likelihood of engagement in criminal behavior over time. In the second book, ${ }^{30}$ they revise part of the previous work, especially emphasizing how adult life leads to an specialization of the criminal career or its abandonment. Analyzing the data by using sophisticated statistical models, the authors demonstrated that individual factors of predisposition to criminal behavior interact with social factors to determine the start, continuity and change in that trend. This way, not only could they estimate the probability of a given individual committing a crime, already from the moment he/she was born, but, further, they were able to identify the critical moments over the course of a

\footnotetext{
${ }^{27}$ Harvard Law School researchers who in the 1940s sought to describe the determinants of criminal behavior from a psychological perspective. (Cullen and Agnew, 2006, p. 489)

${ }^{28}$ The adolescents classified as delinquent originated from two juvenile halls of Massachusetts, while those classified as non-delinquent were picked from public schools of Boston.

${ }^{29}$ Sampson and Laub (1993)

${ }^{30}$ Laub and Sampson (2003)
}

lifetime that would concur to an individual getting involved in a criminal activity or, instead, giving it up.

In view of developments of such nature, the - so to say - "natural" way to follow open to Brazilian scholars in the 1980s and 90s was to invest academically in criminology - which should translate into their creating independent databases and mobilizing sophisticated methodological resources so as to causally explain criminal behavior. But this was not the course taken in Brazil. Even though, by the mid 1980s, nobody doubted the heuristic potential of criminology, any actual academic investment in that discipline would have to wait, as the wider context of institutional reform that marked the time ended up driving criminality studies in another direction.

Brazil's new Federal Constitution, which would be promulgated in 1988, imposed a comprehensive reform of governmental institutions in general, and in special of those responsible for criminal justice administration. These reforms demanded a series of studies that could serve as the basis for new propositions to be formulated in order to alter the working standards of the organizations comprising the criminal justice system, and to adapt them to the requirements of the new Constitution. That demand eventually captured all the available energy of scholars, while any possible interest in making academic investments in criminological theory vanished in the air. ${ }^{31}$

Despite the fact that Criminology has already been institutionalized as an academic discipline related to sociological studies in a number of countries for decades, in Brazil it remains - at best - as a branch of legal studies or as a legatee of the positivist lessons taught more than a century ago. ${ }^{32}$

\footnotetext{
${ }^{31}$ It is of some interest to note that although a real criminology has not yet developed in Brazil, criminality has been a theme approached by several disciplines, notably: anthropology (DaMatta, 1982; Kant de Lima et al., 2000 , Oliven, 1980, Zaluar, 1985), economy (Cerqueira, 2012), medicine (Peres, 2011) for not mention sociology. Without ignoring the importance of this body of knowledge, we are trying to access the obstacles preventing the development of strong sociological theories that could address the causes and consequences of crime in Brazil, as expected by Coelho in his cited article of 1980.

${ }^{32}$ It is important to note that the birth of Criminology in Brazil is a consequence of the expansion of interest among forensic physicians in finding the criminal man in a positivistic perspective. Since it is a very specific ramification under criminological studies, it is always a type of qualified Criminology. As noted by Salvatore and Sozzo (2007), "Positivism criminology entered Brazil through medical schools concerned with questions of race and social hygiene. Brazil provided the clearest example of the doctrine defended by Italian positivists but, at the same time, local criminologists tried to differentiate themselves from the notion of a universal type of "born delinquent." Raymundo Nina Rodrígues, one of the founders of the Bahia School, studied the pathologies associated with racial heritage. (...) In this critique to the 1890 penal code, Nina Rodrígues proposed to adequate people's penal responsibility to racial and climatic differences."
} 
While it is true that any interest in the development of academic criminology in a sociological perspective vanished like smoke in the air, a new pathway was nevertheless opened: turning sociology of crime into an applied discipline. Antônio Luiz Paixão kick-started the process as he promoted, in 1985, the first ever reported partnership in Brazil between the police and a governmental institution of education and research, namely, the João Pinheiro Foundation. ${ }^{33}$ This way of thinking the academic activity, bonded to the possibility of transforming public security actions, would make a definitive mark in the field of sociology of crime in Brazil $^{34}$.

Moreover, upon conceiving in that year of 1985 this pioneer partnership between academia and the police, Paixão further envisages and starts off a first-ever effort to develop an ambitious research project aimed at understanding the dynamics of crime vis-à-vis the very operating standards of the police organization. Hence came up the first software for geoprocessing of police occurrences. At that time, the objective was to systematize police occurrences, marking with different colors the municipalities with higher rates of violent crime in the state [of Minas Gerais], while at the same time making a broad survey within the realm of the military police (which in Brazil is a police force outside the armed forces) with the purpose of unveiling the system of beliefs, values and attitudes prevailing among officers and their subordinates. Ultimately, the resulting research material was expected to enable different training programs to be structured according to rank, while further preparing commanders for the various scenarios they were likely to face in the different environments mapped as indicated above.

Paixão did not live long enough to actually conduct the research and unfold it into policies for police education and crime prevention, but one of his colleagues, Cláudio Beato, did invest in a partnership

\footnotetext{
${ }^{33}$ As pointed by Leeds (2011), Paixão was the first intellectual to realize that police, as an institution, will never change if the academy does not take an important role in this process. Thus, as a researcher at Fundação João Pinheiro, he constructed an agreement with Polícia Militar de Minas Gerais (PMMG) in which all the officials should take specialization courses in this institution in order to be promoted to the next carrier level. The course in the FJP would be taught only by academics, without any connection to the police or military forces. Using of this mechanism, he was able to reframe the perspectives of police formation in Brazil and open the police forces for a different thought of police services in a democratic society.

${ }^{34}$ In that regard, it is worthwhile mentioning the experience of the Núcleo Fluminense de Estudos e Pesquisas (NUFEP/UFF), coordinated by Roberto Kant de Lima. Ever since the year 2000, Lima has run a Specialization Course in Criminal Justice and Public Security, characterized by being an exchange between academicians and police, rather similarly to what had been proposed by Antônio Luiz Paixão in the 1980s. For further information, see: http://www.proppi.uff.br/nufep/cursos
}

with geographers and statisticians to operationalize the shift in focus that it heralded: from the understanding of how law-enforcement organizations work to the way by which the crime records they produce get distributed in time and space in large metropolises. From that point on, police actions would be guided by reference to "criminal patches" outlined in colors on the maps of big cities, indicating places with higher crime rates and the times of the day or night when most offenses tend to happen. ${ }^{35}$ By detailing this sort of Zip Law - given the concentration of crime in certain areas, over time -, these studies could guide the action of Minas Gerais police organizations, causing them to take on a new concern with the organization of urban space which, in addition to preventing crime, would contribute to reducing the feeling of insecurity among the population. ${ }^{36}$ Despite the fact that such approach did not catch on so widely among academicians, it did radically change the way security professionals deal with the phenomenon, all the way from planning to evaluation of the effectiveness of their action ${ }^{37}$.

Following this pioneer experience, there appeared a multiplicity of research centers structured around the new demand posed by public security departments and police organizations for technical consultancy both in the area of training as well as in planning, monitoring and evaluation of public policies. From the northern state of Pará all the way to Brazil's southernmost state of Rio Grande do Sul, there has been a noticeable increase in the number of researchers academically trained to meet the new demands posed by those organizations. The sociologists themselves have ascended to positions in the executive until then monopolized by lawyers, law enforcement professionals, police officers and even members of the armed forces.

In Brazil's northern tip state of Amapá, a sociologist was sworn in as state secretary for public security in

\footnotetext{
${ }^{35}$ Despite the fact that the criminal statistics used in plotting these maps are administrative records, suffering therefore from some of the aforementioned vices, the act of locating the main focuses of police work did allow the police to rethink their procedures and, as a consequence, the way they deployed their personnel in both time and space.

${ }^{36}$ This new understanding of the determinants of crime dynamics derives from the social disorganization theory of Shaw and McKay (1942), which was one of the subsidies used by the Centro de Estudos de Criminalidade e Segurança Pública (CRISP), among other instruments, for better understanding crime distribution in time and space.

${ }^{37}$ The PhD thesis submitted by Ana Luíza Vieira de Azevedo in September 2012 as she completed the graduate program in Public Administration at FGV shows how it is impossible today to think the operational planning of police organizations without making use of this methodology of criminal analysis, introduced in an innovative way in Minas Gerais. The author herself comes to the conclusion that the techniques currently used by the police forces of Rio de Janeiro were learnt at quantitative methodology and criminal analysis courses offered by UFMG or by professors from this university.
} 
2011; in Minas Gerais, another sociologist was appointed as the sub-secretary for Social Defense from 2003 to 2008; and, in 2003, [sociologist] Luiz Eduardo Soares took office as national secretary for public security. ${ }^{38}$ Also, it is worth noting that the politicaladvisory roles played by some scholars such as José Luiz Ratton in Pernambuco (2007-2013); Túlio Khan in São Paulo (2005-2010), Gláucio Soares in the Distrito Federal (1995-1999) and others.

But, if all went so smoothly in this partnership with the federal, state and - more recently - municipal executive; if - furthermore - researchers are well aware of the need for methodological improvements to better understand the dynamics of crime and security; then why is it that Brazil still has one of the highest murder rates in the planet? What has failed, both from the point of view of the advancements seen in the field of sociology of crime and from the point of view of the development of public policies?

The answer, we believe, may lie in the fact that we did not make good, timely use of that formidable corpus of knowledge to which Edmundo Campos Coelho referred more than 30 years ago. Not exactly that corpus of knowledge as consolidated at the time, but also what has been added to it by now, after 30 years have elapsed. In fact, in the 1990s, as Brazilian researchers initiated their activities as consultants in the public sector, they were still at the very early stages of their training as criminologists. Several of the approaches that had already been known since long in the United States (such as the theory of social disorganization of the 1940s, or the critical criminology of the 1970s) were just arriving in Brazil. These theories arrived here without being matched against each other or subjected to tests, or even being challenged as to their applicability to the Brazilian case. Instead, they were being absorbed uncritically by researchers seeking to understand the causes of crime. Thus, as this premature partnership was being established between "sociologists" under training and public administrators eager for immediate solutions capable of ending criminality within six months or so, it often met with failure, particularly insofar as achieving any progress in the area was concerned.

As a matter of fact, the past two decades were marked by a series of studies that advanced only little

\footnotetext{
${ }^{38}$ Luiz Eduardo Soares was Brazil's National Secretary for Public Security from January to October 2003.
}

in terms of incorporating old criminological theories (produced in other countries around the world) into the national scenario and local theory production. Scarcely any progress has been made in terms of creating new methodologies for a more totalizing analysis of the problem or for structuring our databases. The focus was fundamentally this only: responding to the demands for public policies capable of reducing crime and increasing security. To that effect, Brazilian researchers devoted themselves to describing the phenomenon of crime and the modus operandi of public agencies in charge of tackling the problem, actually turning public policies into "corrections of course" made by reference to the problems pointed out in those descriptions. ${ }^{39}$ The result of this persistent backwardness with regard to academic criminology is that we are still surprised at the occurrence, in Brazil, of phenomena already well known by specialized literature. One particular example stands out: the occurrence of inflexions in criminality rates. As Michel Misse pointed out during a recent interview: "We are perplexed at the fall of homicide rates in São Paulo (...) See our difficulty in understanding this one phenomenon, relevant as it may be, which is the sharp fall in homicide rate in São Paulo" ${ }^{\prime 4}$. Misse is referring here to the fall in those rates seen from 2000 to 2011 . The difficulty in explaining this phenomenon resides, in our understanding, in the lack of local studies capable of articulating distinct dimensions of analysis, be it of an individual, contextual or organizational nature, as authors such as George Kelling and Catherine Coles were already doing back in 1996, or as, more recently, Franklin Zimring did as he studied the fall in homicides in New York. ${ }^{41}$ Had there been an emulation of works of that nature in Brazil, then there would probably not be so much "perplexity" in face of the aforementioned phenomenon. Furthermore, there would be no reason for such dismay tone, for instance, in this conclusion of a very recent work on declining murder rates in the city of São Paulo:

\footnotetext{
${ }^{39}$ To understand how Brazil's political history marked the development of criminology in the country, see Zaluar (2004)

${ }^{40}$ Misse (2011)

${ }^{41}$ See Kelling and Coles (1996), Kelling (2009) and Zimring (2011). In New York, traditional policies for fighting crime (for instance, increase in number of policemen or mass incarceration) failed to bring crime rates down to expected levels. However, when these actions were combined with the effects from changes (1) in the economy, (2) in the patterns of drug use and (3) in the demographic makeup of the cities (changes in behavior as the population ages), such as prescribed by criminological theories of "synthesis", then those same policies turned into important actions to reduce crime in New York. Which means to say that, when the various causative factors involved are jointly operationalized, rather than in isolation, then it is possible to perceive the existing interactions between them and, therefore, practical effects in terms of reduced incidence of crime.
} 
It is important to consider, however, the limitations of this descriptive study whose objective was to draw TMH [taxa de mortalidade por homicídios, or murderrelated mortality rate] trends over time per age, gender, race and socioeconomic condition. The unavailability of temporal data on potential social determinants of declining homicide rates renders unfeasible, at this moment, to support any causal inferences on solid bases. In this sense, the descriptive analysis made herein is but a first step, necessary for the development of hypotheses on potential causes of changes in number of homicides over time, to be tested at a later moment. $^{42}$

The complacency and admission of one's own incapacity to go beyond the descriptive register, as expressed in the above quotation, reflect rather well the dismal state in which the area of sociology of crime presently finds itself in Brazil, when it comes to explaining criminality rates.

In view of the above situation, reported by researchers from Núcleo de Estudos da Violência (NEV), one of the most important centers of sociology of crime in Brazil, what could be done to prevent any further "surprise" in face of phenomena that have been so thoroughly discussed in the specialized literature, and to enable the production of more effective public policies designed to reduce the incidence of crimes and criminals?

One of the answers suggested by specialists in the area is that it would be necessary to set up a tripod comprising (1) the study and teaching of criminological theory, (2) the production of more consistent databases in terms of profiles and motivations to engage in a criminal career; (3) a more solid training in quantitative methods in general and in spatial analysis techniques such as geoprocessing. In a recent paper, Claudio Beato elaborated on the first of these three points. ${ }^{43} \mathrm{He}$ argued that the teaching of criminological theory requires the creation of master's level programs with autonomy in relation to sociology departments. Such courses should have as their purpose scrutinizing theories on crime and on the workings of criminal

\footnotetext{
${ }^{42}$ Free translation form Peres et al. (2011, p. 25).

${ }^{43}$ Beato (2012)
}

justice system organizations. This way, he believes, it would be possible to create among us a "critical mass" for the operationalization of studies capable of arriving at explanations applicable to the Brazilian case. There are those, nonetheless, that do not share in this optimism with regard to the potentialities of criminology as an autonomous discipline.

David Garland, for one, argues that the increasing isolation of criminology from departments of social sciences has been making it more and more unable to deal with new modalities of crime such as terrorism and genocide. ${ }^{44}$ But since we do not have these problems in Brazil, perhaps we may just ignore Garland's objections.

With regard to the weak training in quantitative methodology, this was a factor indicated by Gláucio Soares ${ }^{45}$ as being the Achilles heel of social sciences. In fact, Brazilian scholars are scarcely familiar even with the aforementioned linear hierarchical models - for over ten years now routinely used in the United States in the exam of determinants of crime in Chicago. ${ }^{46}$ Finally, it is no use offering cutting-edge quantitative training in the absence of databases by means of which such methods can be operationalized. This means that, in contrast with what happens in the area of social mobility - for which the PNAD can be used as an independent source of information -, the main sources of information in the area of sociology of crime are still the databases kept by police organizations and the prison system, with all their biases as highlighted above. Adding to those, in some situations, are the databases belonging to the Mortality Information System of the Ministry of Health, largely used when researchers want to understand the profile of those who die as a result of violence in Brazil. However, given the fact that these records are fed by Forensic Medicine Institutes, which in turn are coordinated by law enforcement organizations, some biases of police selectivity find their way into the system, as recently demonstrated in an analysis by Daniel Cerqueira. ${ }^{47}$ Even PNAD's supplement on victimization and access to justice - which could contribute with the generation of useful data to this area - is rather sporadic, having been produced only in 1988 and 2009. The first

\footnotetext{
${ }^{44}$ See Garland (2009). For a recent review of works on organized crime in Brazil - which requires political articulation between various modes of crime see Zaluar (2004, p. 224 and following).

${ }^{45}$ Soares (2005)

${ }^{46}$ Raudenbush et al. (2003); Raudenbush and Sampson (1999a, 1999b); Sampson et al. (1997)

${ }^{47}$ See Cerqueira (2011)
} 


\section{Annex 1: Some Theorization Efforts in the Area of Criminality in the 20th Century}

\begin{tabular}{|c|c|c|c|}
\hline Effort & Year & Author & How the theory was tested in the USA \\
\hline Strain Theory & 1938 & Robert Merton & Statistical correlations between unemployment or wage levels and probability to commit crimes. \\
\hline $\begin{array}{l}\text { Social Disorganization } \\
\text { Theory }\end{array}$ & 1942 & Shaw \& MacKay & $\begin{array}{l}\text { Ethnographic studies and historical maps showing that the more seriously deteriorated areas of a } \\
\text { city are also those that show high crime rates and other "incivilities" over time. }\end{array}$ \\
\hline $\begin{array}{l}\text { Differential Association } \\
\text { Theory }\end{array}$ & 1947 & Sutherland & $\begin{array}{l}\text { Ethnographic studies on members of criminal groups and, further, made from databases collecting } \\
\text { longitudinal information on differential "associations" of an individual over his/her life span. }\end{array}$ \\
\hline $\begin{array}{l}\text { Internal and External } \\
\text { Control Theory }\end{array}$ & 1951 & Albert Reiss & $\begin{array}{l}\text { Statistical tests based on opinion surveys combined with measurements of locally existing control } \\
\text { mechanisms. }\end{array}$ \\
\hline $\begin{array}{l}\text { Status Deprivation and } \\
\text { Delinquent Subculture } \\
\text { Theory }\end{array}$ & 1955 & Albert Cohen & $\begin{array}{l}\text { Ethnographic studies on deviant groups structured in poor downtown residences of major North } \\
\text { American cities. }\end{array}$ \\
\hline $\begin{array}{l}\text { Crime and Delinquency } \\
\text { Containment Theory }\end{array}$ & 1956 & Walter Reckless & $\begin{array}{l}\text { Statistical tests based on opinion surveys combined with measurements of locally existing control } \\
\text { mechanisms. }\end{array}$ \\
\hline Neutralization Theory & 1957 & $\begin{array}{l}\text { Gresham Sykes \& } \\
\text { David Matza }\end{array}$ & Ethnographic work aimed at understanding how neutralization occurred within the groups observed. \\
\hline $\begin{array}{l}\text { Theory of the three types of } \\
\text { control }\end{array}$ & 1958 & Ivan Nye & $\begin{array}{l}\text { Statistical tests based on opinion surveys combined with measurements of locally existing control } \\
\text { mechanisms. }\end{array}$ \\
\hline $\begin{array}{l}\text { Differential Opportunity and } \\
\text { Delinquent Subculture } \\
\text { Theory }\end{array}$ & 1960 & $\begin{array}{l}\text { Richard Cloward \& } \\
\text { Lloyd Ohlin }\end{array}$ & $\begin{array}{l}\text { Ethnographic studies on deviant groups of various kinds, aimed at building their concept of three } \\
\text { main groups: relative deprivation, status deprivation and satisfaction derived from risk. }\end{array}$ \\
\hline Conflict Theory & 1960 & $\begin{array}{l}\text { Richard Quinney } \\
\text { William Chambliss } \\
\text { Austin Turk }\end{array}$ & $\begin{array}{l}\text { Multiple analyses based on studies on public opinion about crimes, as well on official databases } \\
\text { enabling verification of whether racial, socioeconomic, gender and age-group disparities would } \\
\text { determine detention, conviction and nature of the punishment to which the criminal is sentenced. }\end{array}$ \\
\hline Social Learning Theory & 1966 & Ronald Akers & $\begin{array}{l}\text { Longitudinal surveys mapping not only the nature of peers, but also the strength of the bond } \\
\text { established with each of them. }\end{array}$ \\
\hline Social Bond Theory & 1969 & Travis Hirschi & $\begin{array}{l}\text { Statistical tests based on longitudinally-built databases, including variables enabling the } \\
\text { operationalization of the concepts of attachment, commitment, participation and belief. }\end{array}$ \\
\hline Critical Criminology Theory & 1973 & $\begin{array}{l}\text { lan Taylor } \\
\text { Paul Walton } \\
\text { Jock Young }\end{array}$ & $\begin{array}{l}\text { Comparison of crime rates and types of crime seen in capitalist societies with those verified in } \\
\text { socialist societies. }\end{array}$ \\
\hline Routine Activity Theory & 1979 & $\begin{array}{l}\text { Lawrence Cohen \& } \\
\text { Marcus Felson }\end{array}$ & Correlating crime rates with information on family activities, consumption habits and line of business. \\
\hline $\begin{array}{l}\text { Social Efficacy Theory (or } \\
\text { revised social } \\
\text { disorganization theory) }\end{array}$ & 1989 & $\begin{array}{l}\text { Robert Sampson } \\
\text { Bryan Groves }\end{array}$ & $\begin{array}{l}\text { Employing linear hierarchical models with the purpose of verifying whether, when individual } \\
\text { variations are controlled, the structural conditions of a neighborhood in fact determine criminal } \\
\text { behavior. }\end{array}$ \\
\hline Self-control Theory & 1990 & $\begin{array}{l}\text { Michael } \\
\text { Gottfredson \& } \\
\text { Travis Hirschi }\end{array}$ & Statistical tests based on behavior surveys mainly conducted among university students. \\
\hline
\end{tabular}

national survey on victimization, funded by the Ministry of Justice and operationalized by Datafolha, is an example of the difficulties faced when trying to collect information in this area, for - despite the fact that it has been running for almost three years already - its database has not yet been completed. ${ }^{48}$

The fact remains that, given the lack of information that would allow an understanding of how the context can interfere in the production and reproduction of factors causing crime; little will be advanced towards understanding the determinants of criminality and violence. In such a scenario, the organizations comprising the criminal justice system will keep on

\footnotetext{
${ }^{48}$ According to Catão (2010), there are in Brazil 29 regional victimizations surveys; most of them were carried out in the southeast states as São Paulo (ILANUD), Minas Gerais (CRISP), Rio de Janeiro (ISP). However, due to a regional focus, these databases cannot be used to provide a national figure of crime victimization in Brazil.
}

operating as they did decades ago, while the widely available financial resources for conducting research and offering consultancy in the area of public security will remain incapable of reversing the bleak picture of one violent death every 10 minutes, indicated by recent data disclosed by the Avante Brasil Institute.

\section{ACKNOWLEDGEMENT}

The Authors acknowledge the funding support provided by Foundation for Research Support of the State of Minas Gerais (Fundação de Amparo à Pesquisa do Estado de Minas Gerais - FAPEMIG).

\section{REFERENCES}

Adorno, Sérgio (1995). Discriminação racial e justiça criminal em São Paulo. Novos Estudos, São Paulo, Cebrap, n. 43, p. 4563.

Barreira, César; Adorno, Sérgio (2010). A violência na sociedade brasileira. In: Martins, Carlos Benedito e Martins, Heloisa Helena T. Souza (org). Horizontes das Ciências Sociais no Brasil: Sociologia. São Paulo: ANPOCS. Pp. 303-374. 
Beato, Cláudio (2012). Crimes e cidades. Belo Horizonte: UFMG.

Becker, Gary (1968). Crime and punishment: an economic approach. In: Journal of Political Economy. No. 76. Pp.0-169.

Catão, Yolanda (2010). Quadro das pesquisas de vitimização já realizadas no Brasil. In: Anuário do Fórum Brasileiro de Segurança Pública. Available in: http://www.forumseguranca. org.br/storage/download//anuario_ii__pesquisa_de_vitimizacao_-_notas_metodologicas 1.pdf

Cerqueira, Daniel (2012). Mortes Violentas Não Esclarecidas e Impunidade no Rio de Janeiro. In: Working Paper 026. Rio de Janeiro: Rede de Economia Aplicada (REAP).

Cicourel, Aaron V. (1968). The Social Organization of Juvenile Justice. New York: Wiley.

Coelho, Edmundo Campos (1978[2005]). "Da criminalização da marginalidade à marginalização da criminalidade." Revista de Administração Pública. v. 12, n. 2, abr./jun. p.139-61.

Coelho, Edmundo Campos (1980[2005]). Sobre sociólogos, pobreza e crime. In: Dados: Revista de Ciências Sociais. V. 23, n. 3, p. $377-83$.

Coelho, Edmundo Campos (2005). A Oficina do Diabo e outros Estudos sobre Criminalidade. Rio de Janeiro: Record. Escritos póstumos organizados por Magda Prates Coelho.

Cullen, Francis T.; Agnew, Robert (2006). Criminological Theory: past to present: essential readings. Los Angeles: Roxbury Publishing Company.

Damatta, Roberto (1982). "As raízes da violência no Brasil". In: Paoli, Maria Célia et alii. A Violência brasileira. São Paulo, Brasiliense. Pp. 11-44.

Garland, David (2009). "Disciplining criminology?" In: Sistema Penal \& Violência. Porto Alegre, Volume 1, Número 1, p. 114-125 julho/dezembro.

Kant De Lima, Roberto; Misse, Michel; Miranda, Ana Paula Mendes (2000). Violência, criminalidade, segurança pública e justiça criminal no Brasil: uma bibliografia. BIB: Revista Brasileira de Informação Bibliográfica em Ciências Sociais, Rio de Janeiro, v. 50, p. 45-123.

Kelling, George L (2009). "How New York Became Safe: The Full Story: a citywide effort, involving many agencies and institutions, helped restore order." In: City Journal. 17 July.

Kelling, George; Coles, Caterine (1996). Fixing Broken Windows: Restoring Order and Reducing Crime in our Communities. New York: Free Press.

Laub, John H; Sampson, Robert (2003). Shared Beginning, Divergent Lives: Delinquent Boys to Age 70. Cambridge, MA: Harvard University Press.

Leeds, Elizabeth (2011). Prefácio. In: Lima, Renato e Ratton, José Luiz. As ciências sociais e os pioneiros nos estudos sobre crime, violência e direitos humanos no Brasil. São Paulo: ANPOCS.

Martins, Heloisa Helena T. Souza (org) (2010). Horizontes das Ciências Sociais no Brasil: Sociologia. São Paulo: ANPOCS..

Misse, Michel (2008). Sobre a acumulação social da violência no Rio de Janeiro. In: Civitas. V. 8 n. 3. Porto Alegre, set.-dez. Pp. 371-385.
Misse, Michel (2011). Depoimento. In: Lima, Renato e Ratton, José Luiz. As ciências sociais e os pioneiros nos estudos sobre crime, violência e direitos humanos no Brasil. São Paulo: ANPOCS

Oliven, Ruben George (1980), "A violência como mecanismo de dominação e estratégia de sobrevivência", Dados, 23(3):

Paixão, Antônio Luiz (1982). A organização policial numa área metropolitana. Dados: Revista de Ciências Sociais. Rio de Janeiro. V. 25 , n. 1, p. $63-85$

(1983). "Crime e criminosos em Belo Horizonte, 1932-1978". In: Pinheiro, Paulo Sérgio (Org.). Crime, violência e poder. São Paulo: Brasiliense. pp. 13-44.

Peres, Maria Fernanda et al. (2011). "Queda dos homicídios em São Paulo, Brasil: uma análise descritiva". Revista Panamericana de Salud Publica 29(1): 17-26. http://dx.doi.org/10.1590/S1020-49892011000100003

Raudenbush, S.W. , Johnson, C. and Sampson, R. J. (2003). A multivariate, multilevel Rasch model for self-reported criminal behavior. Sociological Methodology, Vol. 33(1), 169-211. http://dx.doi.org/10.1111/j.0081-1750.2003.t01-1-00130.x

Raudenbush, S.W., \& Sampson, R. (1999a). Assessing direct and indirect effects in multilevel designs with latent variables. Sociological Methods \& Research, 28(2),123-153. http://dx.doi.org/10.1177/0049124199028002001

(1999b). Ecometrics: Toward a science of assessing ecological settings, with application to the systematic social observations of neighbourhoods. Sociological Methodology, 29, 1-41. http://dx.doi.org/10.1111/0081-1750.00059

Vargas, Joana (2014). "Fluxo do Sistema de Justiça Criminal". In Renato Sérgio de Lima, José Luiz Ratton, Rodrigo Azevedo. (Org.). Crime, polícia e justiça no Brasil. São Paulo: Contexto.

Salvatore, Ricardo and Sozzo, Maurício. (2007) Modern criminology in Latin America and the United States. Ms.

Sampson, Robert; Laub, John H (1993). Crime in the making: pathways and turning points through life. Cambridge, MA: Harvard University Press.

Sampson, R.J., Raudenbush, S.W., \& Earls, F. (1997). Neighbourhoods and violent crime: A multilevel study of collective efficacy. Science, $277,918-924$. http://dx.doi.org/10.1126/science.277.5328.918

Soares, Gláucio (2005). O calcanhar metodológico da ciência política no Brasil. In: Sociologia, Problemas e Práticas, n. ${ }^{\circ}$ 48. pp. 27-52.

Zaluar, Alba (1985). A máquina e a revolta. São Paulo: Brasiliense.

(2004), Integração Perversa: Pobreza e Tráfico de Drogas, Rio de Janeiro:FGV.

Zimring, Franklin E. (2011). The city that became safe: New York's lesson for urban crime and its control. New York: Oxford University Press.

(C) 2014 Freitas and Ribeiro; Licensee Lifescience Global.

This is an open access article licensed under the terms of the Creative Commons Attribution Non-Commercial License (http://creativecommons.org/licenses/by-nc/3.0/) which permits unrestricted, non-commercial use, distribution and reproduction in any medium, provided the work is properly cited. 